\title{
In-Vivo Corrosion Characterization and Assessment of Absorbable Metal Implants
}

\author{
Mokhamad Fakhrul Ulum ${ }^{1}$ (), Wahyu Caesarendra ${ }^{2}$, Reza Alavi ${ }^{3}$ and Hendra Hermawan ${ }^{3, *}$ (i) \\ 1 Faculty of Veterinary Medicine, Bogor Agricultural University, Bogor 16680, Indonesia; ulum@apps.ipb.ac.id \\ 2 Faculty of Integrated Technologies, University of Brunei Darussalam, Gadong BE1410, Brunei Darussalam, \\ \& Department of Mechanical Engineering, Diponegoro University, Semarang 50275, Indonesia; \\ wahyu.caesarendra@ubd.edu.bn \\ 3 Department of Mining, Metallurgical and Materials Engineering \& CHU de Québec Research Center, \\ Laval University, Quebec City, QC G1V 0A6, Canada; reza.alavi.1@ulaval.ca \\ * Correspondence: hendra.hermawan@gmn.ulaval.ca
}

Received: 24 March 2019; Accepted: 25 April 2019; Published: 26 April 2019

\begin{abstract}
Absorbable metals have been introduced as materials to fabricate temporary medical implants. Iron, magnesium and zinc have been considered as major base elements of such metals. The metallurgical characterization and in-vitro corrosion assessment of these metals have been covered by the new ASTM standards F3160 and F3268. However, the in-vivo corrosion characterization and assessment of absorbable metal implants are not yet well established. The corrosion of metals in the in-vivo environment leads to metal ion release and corrosion product formation that may cause excessive toxicity. The aim of this work is to introduce the techniques to assess absorbable metal implants and their in-vivo corrosion behavior. This contains the existing approaches, e.g., implant retrieval and histological analysis, ultrasonography and radiography, and the new techniques for real-time in-vivo corrosion monitoring.
\end{abstract}

Keywords: absorbable; biodegradable; corrosion; in-vivo; metal; monitoring

\section{Introduction}

Referring to ASTM F3160-16 standard [1], an absorbable metal, also known as biodegradable metal, can be defined as "an initially distinct foreign material or substance [metal] that either directly or through intended degradation can pass through or be metabolized or assimilated by cells and/or tissue." The degradation begins when the implant and the body fluid interact via the electrochemical mechanism of metal dissolution (corrosion) [2,3]. Ideally, these metals should corrode in the in-vivo at a proper rate without inducing any undesirable reaction from the host. Eventually, they are supposed to perfectly disappear as soon as the new tissue is formed [2].

Iron $(\mathrm{Fe})$, magnesium $(\mathrm{Mg})$ and zinc $(\mathrm{Zn})$-based metals constitute a major part of absorbable metals. They have been studied and proposed for making temporary medical implants such as coronary stents, bone pins and screws, and surgical clips [4]. Animal studies have shown that the stents made of Fe and $\mathrm{Zn}$ are biocompatible for a long-term period [5,6]. Mg-based stents also showed a continuous desirable safety profile when clinically tested in humans [7]. These are only few recent examples of absorbable metal implant development besides the recent commercial launch of $\mathrm{Mg}$ bone screws and pins by a German company [8]. 
Once implanted in the body, an absorbable metal should maintain proper mechanical properties in the course of corrosion. In addition, there needs to be a balance between the amount of released metal ions and the capacity of the body to metabolize (absorb and excrete) them. Therefore, the corrosion rate should be controlled. This can be done by microstructural and metallurgical manipulation and through surface treatment and coatings. The results can be confirmed by various standardized in-vitro corrosion assessment methods, but such standardized techniques have not been introduced for in-vivo corrosion tests. This manuscript is aimed at establishing a common ground for in-vivo corrosion characterization and assessment of absorbable metal implants by reviewing the techniques routinely used and new techniques capable of real-time in-vivo corrosion monitoring.

\section{Corrosion of Absorbable Metals}

The corrosion rates of the three groups of absorbable metals follow this order: Fe-based are lower than Zn-based and both are lower than Mg-based [3,9-11]. As an illustration, the corrosion rate of pure $\mathrm{Mg}$, pure $\mathrm{Fe}$ and pure $\mathrm{Zn}$ after $168 \mathrm{~h}$ of immersion in saline solution at $37^{\circ} \mathrm{C}$ were 4 , 0.2 and $0.6 \mathrm{~mm} /$ year, respectively [12]. Under the in-vivo condition, the slow corrosion of Fe and its alloys becomes more evident [13-15], and the high corrosion rate of Mg-based metals becomes problematic $[5,16,17]$. Various approaches have been employed to control the speed of corrosion in absorbable metals: precise alloying, purification, improved manufacturing process, surface treatment and protective coating (Table 1). It has been shown that alloying with manganese (Mn), palladium $(\mathrm{Pd})$, silver $(\mathrm{Ag})$, gallium $(\mathrm{Ga})$, sulfur $(\mathrm{S})$ and intermetallic compounds accelerated the corrosion of Fe-based metals [6,18-21]. This was obtained also by surface modification approaches, such as vacuum plasma nitriding, silver ion implantation [22,23] and by making composites with polymers [24-26]. On the contrary, purification $[27,28]$, alloying with calcium (Ca), Zn, rare earth elements (RE) and others $[26,29,30]$ as well as coating with bioceramics or biopolymers [31-34] led to a decrease in corrosion rate of $\mathrm{Mg}$-based alloys.

The enhanced corrosion rates of absorbable metals are often only observed during in-vitro tests. Such results have not been reproduced under in-vivo conditions $[35,36]$. Unlike in-vitro conditions under which the test parameters are highly controlled, the in-vivo environment introduces more complexities to the test such as physiological response of living tissues as well as numerous components of body fluid, e.g., water, organic compounds, dissolved oxygen, cations, anions, proteins, amino acids, etc., all of which can affect the corrosion process. [37]. Therefore, there exists a challenge to establish a method for characterizing and assessing the in-vivo corrosion behavior and for correlating the results with those obtained in the in-vitro tests [2,35,37].

\subsection{Correlation of In-Vitro and In-Vivo Corrosion}

The challenge of modeling the complex in-vivo condition in the in-vitro tests as well as the variation in testing parameters and procedures make it difficult to correlate the in-vitro and in-vivo test results. [35]. It has been shown that corrosion rates of $\mathrm{Mg}$ pins obtained from in-vitro tests (immersion in DMEM) were comparable with those obtained from in-vivo experiments (in Sprague-Dawley rats). However, it is still necessary to improve the in-vitro experiments by taking into account the biological components, dynamic condition and mechanical exposure that are present under in-vivo conditions [38]. In an in-situ experiment, the corrosion of an $\mathrm{Mg}$ alloy was electrochemically monitored (real time) in a vascular bioreactor. It was observed that the flow-induced shear stress caused faster mass and electron transfer of the alloy during corrosion [39]. These two examples suggest that certain in-vivo conditions affect the corrosion behavior of absorbable metals and indicate the importance of correlating the results obtained by in-vitro experiments with those of in-vivo tests. Thus, it is necessary to develop a standard methodology to understand how exactly a parameter affects the in-vitro corrosion of a metal. Such a methodology makes it possible for the researchers to compare their results more easily. 
Table 1. Examples of corrosion control methods for absorbable metals.

\begin{tabular}{|c|c|c|}
\hline Materials & Corrosion Test Method and Result & Understanding \\
\hline $\begin{array}{c}\mathrm{Fe}-\mathrm{Ga} \text { alloy system: } \mathrm{Fe}_{81} \mathrm{Ga}_{19} \\
\left(\mathrm{Fe}_{81} \mathrm{Ga}_{19}\right)_{98} \mathrm{~B}_{2} \text { and } \\
\left(\mathrm{Fe}_{81} \mathrm{Ga}_{19}\right)_{99.5}(\mathrm{TaC})_{0.5} \text { fabricated } \\
\text { by arc melting process [6] }\end{array}$ & $\begin{array}{l}\text { Method: Potentiodynamic polarization and } \\
\text { immersion tests in simulated body fluid (SBF) } \\
\text { at } 37^{\circ} \mathrm{C} \text { up to } 28 \text { days. } \\
\text { Results: In ascending order, the corrosion rate } \\
\left.\text { (in mm/year) of pure } \mathrm{Fe}_{1}, \mathrm{Fe}_{81} \mathrm{Ga}_{19}\right)_{99.5}(\mathrm{TaC})_{0.5} \\
\left.\mathrm{Fe}_{81} \mathrm{Ga}_{19} \text {, and } \mathrm{Fe}_{81} \mathrm{Ga}_{19}\right)_{99.5}(\mathrm{TaC})_{0.5} \text { are } 0.13 \pm \\
0.03,0.33 \pm 0.11,0.48 \pm 0.16 \text { and } 0.63 \pm 0.33, \\
\text { respectively }\end{array}$ & $\begin{array}{l}\text { Increasing reactive Ga reduced the } \\
\text { corrosion resistance. However, } \\
\text { adding ternary } \mathrm{B} \text { or } \mathrm{TaC} \text { induced } \\
\text { extremely significant pitting } \\
\text { corrosion as the result of forming } \\
\text { multi-phases on the surface }\end{array}$ \\
\hline
\end{tabular}

Method: Potentiodynamic polarization, electrochemical impedance spectroscopy and immersion tests in Hanks' solution at $37^{\circ} \mathrm{C}$ up to 30 days.

Silver ion was implanted onto pure Fe using a metal vapor vacuum arc technique [23]

Results: The corrosion rates (in $\mathrm{mg} / \mathrm{cm}^{2}$.day) of silver ion-implanted pure Fe were 0.101 (polarization) and 0.055 (immersion), higher than those of pure Fe which were 0.058 (polarization) and 0.048 (immersion)

A rise in the corrosion rate and obtaining more uniform corrosion was attributed to the microgalvanic reaction of $\mathrm{Fe}$ matrix and $\mathrm{Ag}_{2} \mathrm{O}$ particles

Method: Potentiodynamic polarization and

Pure Fe foam-poly(lactic-co-glycolic acid) or Fe-PLGA composite fabricated by a vacuum infiltration technique [24] immersion tests in phosphate-buffered solution (PBS) at $37^{\circ} \mathrm{C}$ up to 28 days.

Results: The corrosion rates of PLGA-infiltrated porous $\mathrm{Fe}$ was $0.72 \mathrm{~mm} / \mathrm{year}$, which is higher than that of PLGA-coated porous Fe (0.42 $\mathrm{mm} /$ year) and pure porous Fe (0.11 mm/year)

Method: Immersion test (hydrogen evolution) in $\mathrm{NaHCO}_{3} / \mathrm{CO}_{2}$-buffered simulated body fluid (SBF) at $37^{\circ} \mathrm{C}$ up to 14 days.

Ultrahigh purity $\mathrm{Mg}$ fabricated via casting and via extrusion [27]

Results: Corrosion rate of as-cast ultrahigh purity $\mathrm{Mg}$ was $10 \pm 3 \mu \mathrm{m} /$ year, which is lower than the as-extruded one ( $28 \pm 2 \mu \mathrm{m} /$ year $)$, and high purity $\mathrm{Mg}(39 \pm 3 \mu \mathrm{m} /$ year $)$

Method: Long-term immersion test (up to 365 days) in Dulbecco's Modified Eagle Medium

(DMEM) supplemented with 10 vol.\% fetal bovine serum buffered with

AZ31 Mg alloy coated with hydroxyapatite (HA) and with octacalcium phosphate (OCP) using a single-step chemical solution deposition method [31]

4-(2-hydroxyethyl)-1-piperazineethanesulfonic acid (HEPES) at $37^{\circ} \mathrm{C}$ and refreshed periodically.

Results: From the measurement of $\mathrm{Mg}$ ion release, the HA-coated AZ31 alloy corroded at $0.056 \mathrm{mg} /$ day or $\sim 20 \%$ slower than the

OCP-coated ( $0.072 \mathrm{mg} /$ day) which both slower than that of uncoated one $(0.12 \mathrm{mg} /$ day $)$

ZM21 Mg alloy spin-coated with four different biodegradable polymers: PLGA, poly(l-lactide acid) (PLLA),

poly(3-hydroxybutyrate) (PHB), poly(3-hydroxybutyrate-co-

3-hydroxyvalerate) (PHH) [32]
Method: Electrochemical impedance spectroscopy and immersion tests in DMEM supplemented by $10 \%(v / v)$ fetal bovine serum (FBS) pre-conditioned at $37^{\circ} \mathrm{C}$ up to 28 days. Results: The weight loss (in $\mu \mathrm{g} / \mathrm{mm}^{2}$ ) decreased from $\sim 55$ for uncoated sample to $\sim 30$ for

PLGA-coated, and to $\sim 15$ for other coated samples (PLLA, PHB, PHH)
The dissolution effect of the polymer as well as its interfacial reaction with Fe substrate accelerated the corrosion

The increase of corrosion rate was due to the influence of

Fe-containing precipitates formed during casting, showing the important role of impurities is deteriorating the corrosion resistance of $\mathrm{Mg}$

The coating added a corrosion barrier where its resistance and stability were higher for the OCP coating than those of the HA coating

The lower corrosion rates of PLLA-, PHB- and PHH-coated samples compared to that of PLGA-coated sample were related to their higher coating resistance due to their lower water permeability

ISO and ASTM have been jointly working to develop standard guides to assess corrosion behavior, metallurgical aspects and biocompatibility of absorbable metals [40]. ASTM recently published two new standards for absorbable metals: the F3160 and F3268 [1,41]. The former provides guidelines to properly characterize and asses the physical, chemical, mechanical and microstructural properties of absorbable metals. It contains inspection instruction for cast and wrought metals [1]. The latter, however, provides guidelines to properly control the test environment, and it contains optional use of a standard absorption control material to make it easier to normalize and compare the results obtained by different researchers [41]. However, neither of the mentioned documents provide biocompatibility or 
in-vivo assessment guides. ISO is supporting the development of ISO/TS 37137-1 and ISO/TR 37137-2 guides for clinical and biological evaluation of absorbable metals [42,43].

\subsection{Material-Tissue Interaction during In-Vivo Corrosion}

Once implanted into the human body, an absorbable metal is continuously exposed to the extracellular tissue fluid. As illustrated in Figure 1, it results in electrochemical dissolution of metal, inducing a multi-step process in the body: protein adsorption, coagulation, acute inflammation, chronic inflammation and foreign body response. The acute interaction generates an interspace (dead space) between the implant and the tissue that is filled with a great amount of body fluid. Then, inflammation of cells takes place in the first week after implantation. The inflammation reduces over time, since the surrounding tissue proliferates into the dead space [44,45].

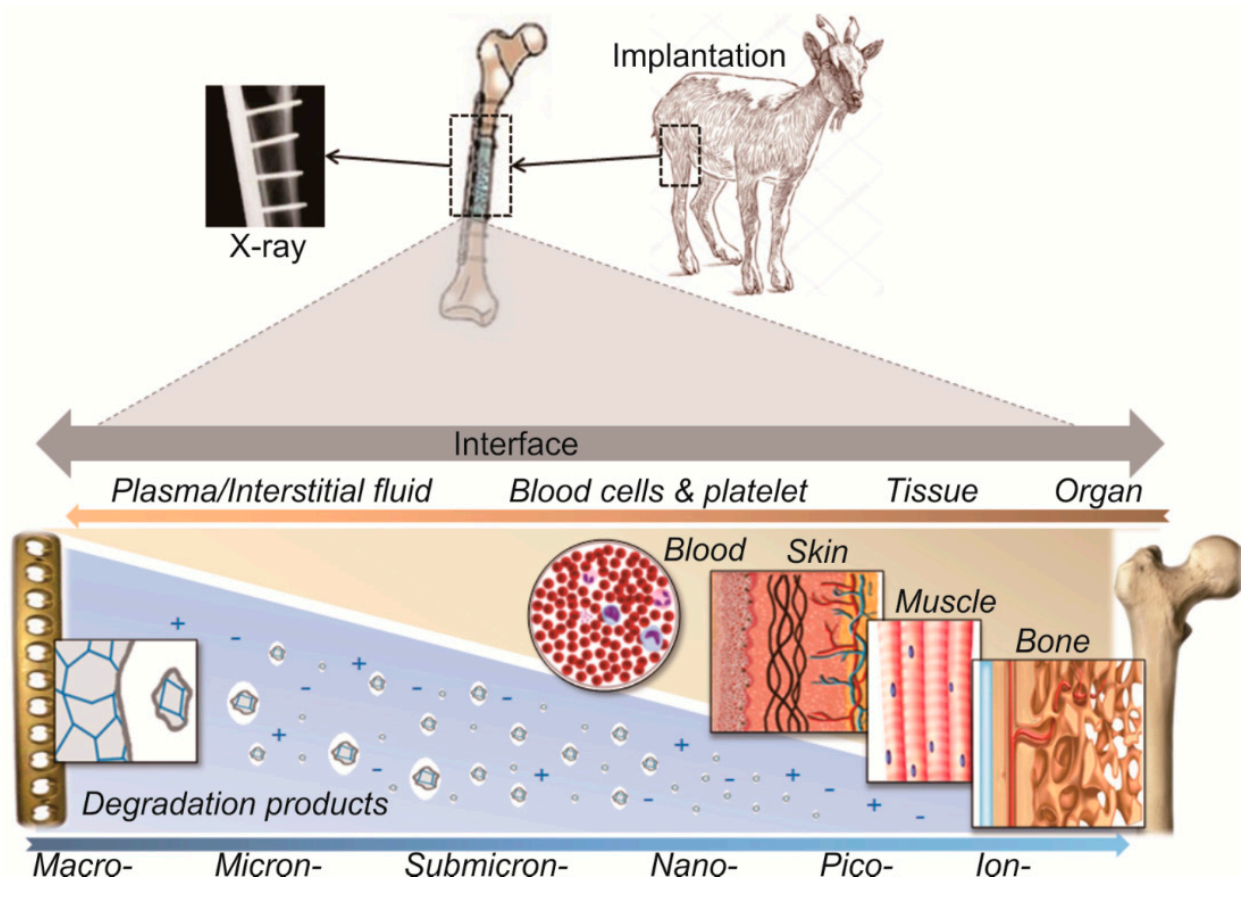

Figure 1. Schematic of potential interaction between an absorbable metal-local tissue interactions followed by the body response. Corrosion starts as the implant is inserted, then the tissue reacts to this foreign body. Corrosion products formed and released into the tissue are fragmented from micron size down to ions, transported by the blood cells and passed into different tissue depending on the implantation site, i.e., bone, muscle, skin, etc.

Corrosion initiates anywhere with potential difference on the surface of metal. It is induced by either microstructural heterogeneity, e.g., impurities, phases, grain boundaries and native oxide layers, or by geometrical variations and environmental conditions, e.g., notch, crevice, coating defect, scratch and oxygen level gradient. Different components constitute the body fluid, e.g., cations and anions, organic compounds, dissolved oxygen, proteins and amino acids. Corrosion of metal (M) in the physiological environment generally involves the following reactions: 
- Anodic reaction:

- Anodic reaction:

- Product formation:

$$
\begin{aligned}
& \mathrm{M} \rightarrow \mathrm{M}^{n+}+\mathrm{n} e^{-} \\
& 2 \mathrm{H}_{2} \mathrm{O}+2 e^{-} \rightarrow \mathrm{H}_{2}+2 \mathrm{OH}^{-} \\
& 2 \mathrm{H}_{2} \mathrm{O}+\mathrm{O}_{2}+4 e^{-} \rightarrow 4 \mathrm{OH}^{-}
\end{aligned}
$$

The released metal ions react with water and other components, producing a layer of corrosion products with a simple composition, e.g., metal hydroxides $(\mathrm{M}(\mathrm{OH}) n)$ or with a complex one, e.g., metal complexes. Reduction of water and/or oxygen consume the free electrons, and hydrogen gas or hydroxide ions are produced as the result. Due to inflammatory response, $\mathrm{pH}$ value drops to 5.3-5.6 in the vicinity of the implant. This may accelerate the corrosion process and decrease the local oxygen level [46]. The inorganic ions like $\mathrm{Cl}^{-}$severely penetrate the $\mathrm{M}(\mathrm{OH}) n$ layer which results in continuous localized corrosion [47]. For other ions, $\mathrm{SO}_{4}{ }^{2-}$ has similar effect as $\mathrm{Cl}^{-}$, however $\mathrm{HPO}_{4}{ }^{2-} / \mathrm{PO}_{4}{ }^{3-}$, $\mathrm{HCO}_{3}{ }^{-} / \mathrm{CO}_{3}{ }^{2-}$ and $\mathrm{Ca}^{2+}$ protect the surface of $\mathrm{Mg}$ and Fe by passivating it. This occurs due to the precipitation of carbonate and phosphate salts on the surface of metal [48,49]. Adsorption of organic molecules such as albumin on the surface of $\mathrm{Mg}$ impede the corrosion in the primary step [50]. On the contrary, amino acid decreases the barrier effect of the passive salt layer that protects $\mathrm{Mg}$ against corrosion [48].

\section{In-Vivo Corrosion Characterization and Analysis}

In order to study the body response to metallic absorbable implants, researchers have successfully employed the approaches used for inert biomaterials [51]. The conventional methods for in-vivo corrosion assessment of absorbable metal implants are implant retrieval characterization, histological analysis, and ultrasonography and radiography.

\subsection{Implant Retrieval Analysis}

On the retrieved implant, corrosion characterization and analysis can be conducted by observing the surface morphology and cross-section by means of a Scanning Electron Microscope (SEM) coupled with an Energy-Dispersive X-ray Spectroscopy (EDS). By comparing the retrieved implant to that of the non-implanted control sample, corrosion rate can be calculated by weight loss or by measuring the metal-oxide layer thickness from the cross-sectional images. Further analysis on the corrosion product can be done using X-ray Photoelectron Spectroscopy (XPS), Fourier-Transform Infrared Spectroscopy (FTIR), or X-ray Diffraction (XRD) to determine the formed, inorganic compounds, organic compounds or crystalline phases, respectively. An SEM-EDS analysis was used to reveal the morphology and chemical elements of the corrosion products on the surface of the retrieved Fe-bioceramic implant after 10 weeks of implantation in the radial bone of sheep (Figure 2a) [52]. A similar instrument was also used to analyze chemical composition on the cross section of an explanted AZ31B Mg screw after 21 weeks of implantation in the femoral bone of rabbit, showing a variation of the element as a function of distance from the bone-implant interface (Figure 2b) [53]. The SEM-EDS also revealed the inorganic compounds formed on a pure Fe pin after 52 weeks of implantation in rat which was then analyzed further based on each element at the tissue-implant interface (Figure 2c) [13]. 

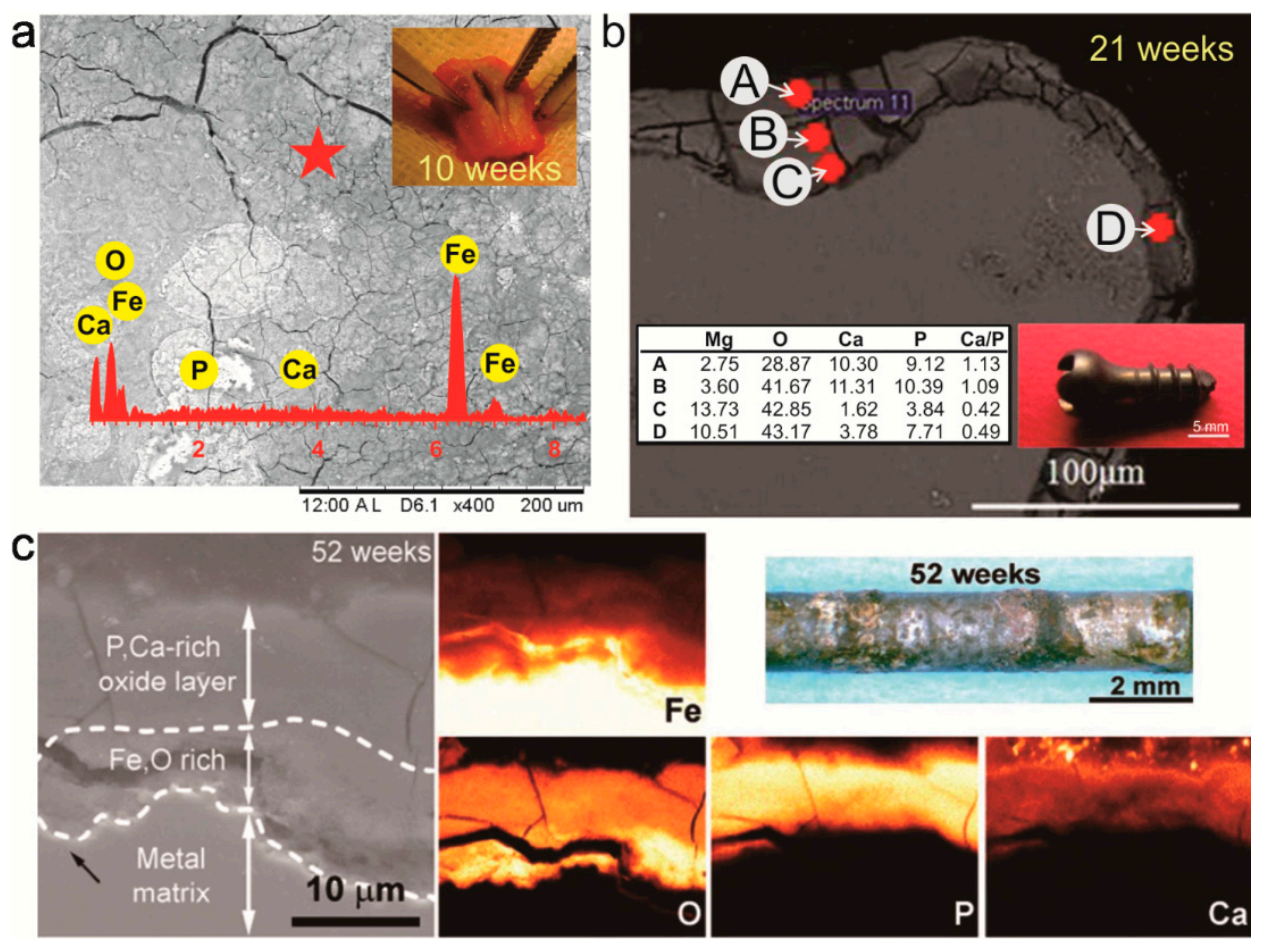

52 weeks
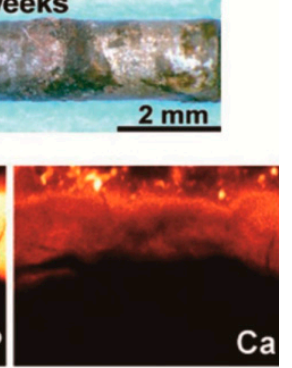

Figure 2. Scanning Electron Microscope-Energy-Dispersive X-ray Spectroscopy (SEM-EDS) analysis on the corrosion product of some retrieval implants: (a) surface of an Fe-bioceramic plate after 10 weeks implanted in sheep having undissolved corrosion product; (b) cross section of AZ31B Mg alloy screw after 21 weeks implanted in rabbit with attached corrosion product having different chemical compositions at different points on the surface; (c) cross section of pure Fe pin after 52 weeks implanted in rat showing the composition of corrosion product on the surface that differs depending on the distance from the implant interface. Adapted with permission from Elsevier and John Wiley and Sons $[13,52,53]$.

\subsection{Histological Analysis}

Histological analysis is usually done at the end of an in-vivo study, where it needs a sacrifice of the animals [54], or a biopsy of the target tissue while the animals are still alive [52]. The harvested tissue is then processed to obtain serial micro-slicing samples of the area of interest, either with or without the retrieved implant in the tissue. The soft histological tissue is processed by infiltrating paraffin into the tissue then serial micro-slicing at $\pm 5-7 \mu \mathrm{m}$ thickness [52]. However, at the presence of the implant or the hard tissue, poly(methyl methacrylate) resin is used prior to micro-slicing with a diamond saw at $\pm 100-200 \mu \mathrm{m}$ thickness [55]. By comparing the images of tissue around the implant to those of control tissue obtained from sham animals, the tissue-implant interaction can be analyzed. This can be done by observing the morphology, number and function of cells that were directly or indirectly in contact with the implant under an optical microscope, SEM, or confocal laser scanning microscope (Figure 3a) [54-56]. The remnant of corrosion products can be viewed and measured in terms of size and distance from the implantation site (Figure 3b) [57]. Contrast stains are also used to reveal the specific cell morphology around the implantation site (Figure 3c) [58]. 


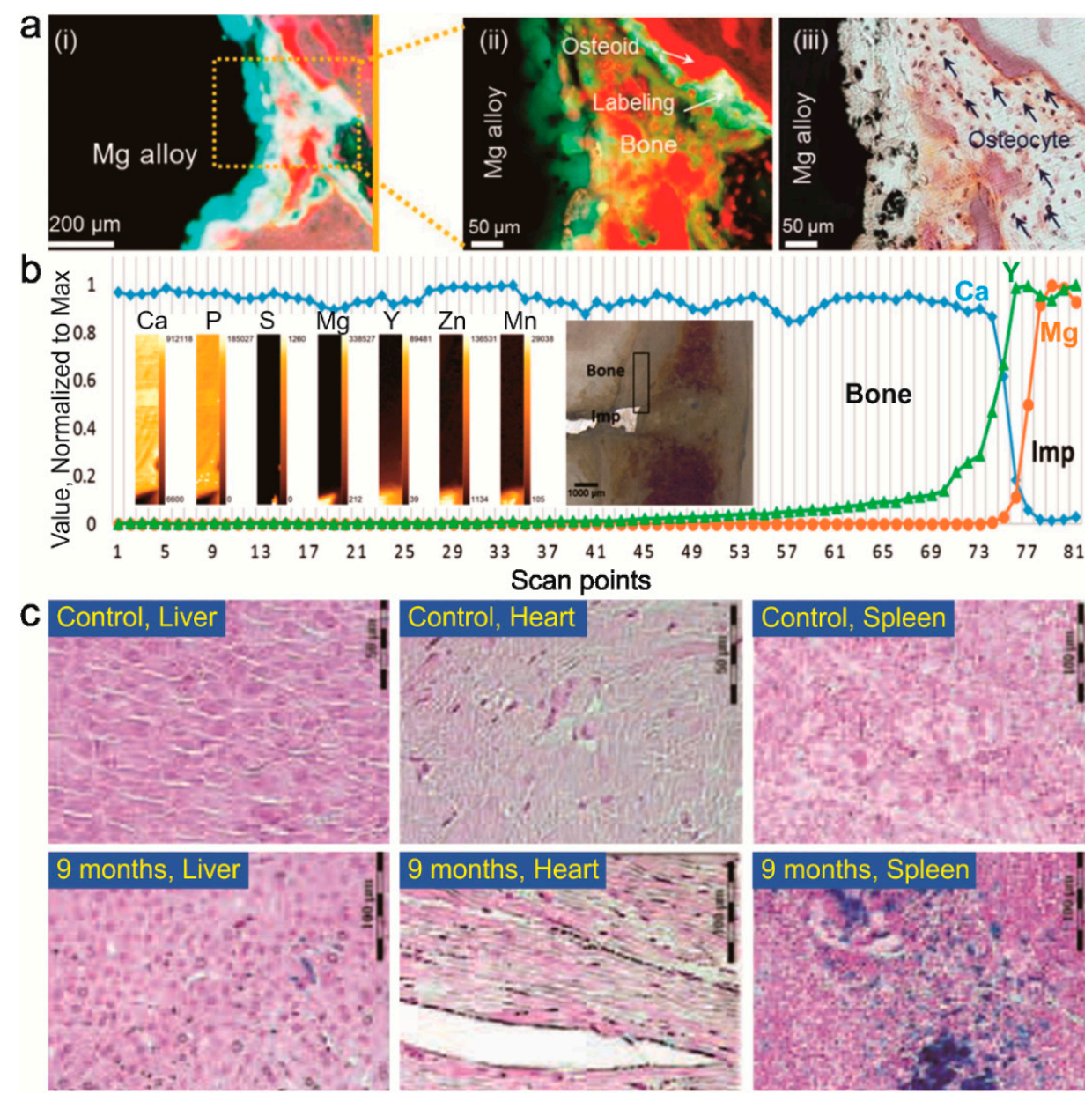

Figure 3. Example of local and systemic histological assessment of tissue-implant interaction: (a) fluorescence image of Villanueva stain on $\mathrm{Mg}$ alloy-contained femoral bone of New Zealand white rabbits after 26 weeks of implantation indicating a formation or differentiation of bone cells at the tissue-implant interface, which would not appear when using general stain of Hematoxillin-Eosine; (b) Micro X-ray Fluorescence ( $\mu$ XRF) elemental mapping of explanted WZ21 Mg alloy from femoral bone of a Sprague-Dawley rat after 12 months of implantation showing an elemental map that helps to understand the spreading of corrosion product in the vicinity of the implant; (c) Prussian blue stain image of liver, heart and spleen of mice after nine months of exposure to Fe stent implantation depicting corrosion product deposit in the organ of interest as a way of systemic evaluation of organs toxicity. Adapted with permission from John Wiley and Sons $[55,56,58]$.

\subsection{Ultrasonography and Radiography}

Ultrasonography (USG) uses a very high frequency sound waves $(>20,000 \mathrm{~Hz})$ to image soft tissue, enabling it to produce a real-time image at different gray scale degrees [52]. The sound wave is reflected by the tissue at different level of echogenicity: hyperechoic (high reflective) by gas-contained and hard tissue, hypoechoic by soft tissue, and anechoic (no reflection) by fluid. The USG's echogenicity was analyzed using ImageJ software (NIH, USA) to quantitatively assess the corrosion of the Fe-bioceramic implant in sheep (Figure 4a) [51]. Different from USG, radiography and tomography use X-rays to produce diagnostic images and is considered as a gold standard for hard tissue monitoring of metal implants. The instrument emits X-rays that are attenuated when they pass through, are reflected or absorbed by the target tissue. Only the pass through X-rays are received by X-ray film or digital $X$-ray sensors to produce images $[59,60]$. Tissue characteristics, such as thickness, density, type of tissue and presence of implant or corrosion product can be differentiated from the gray scale of the 2D 
X-ray images [61]. The gray scale variation indicates some changes both on the implant and the tissue where tissue change becomes more visible around an active (corroding) implant than an inert one [59]. The line-plot profile module of ImageJ software was used to analyze the radiography images of porous Fe implanted in the femoral bone of rat (Figure 4b) [51]. Another analysis uses a radiographic scoring system as a qualitative approach, which was applied to assess the variation of the structure and shape of the femur of New Zealand white rabbits after being implanted with LANd442 Mg alloy pin for over 4-10 weeks (Figure 4c) [61,62].

a
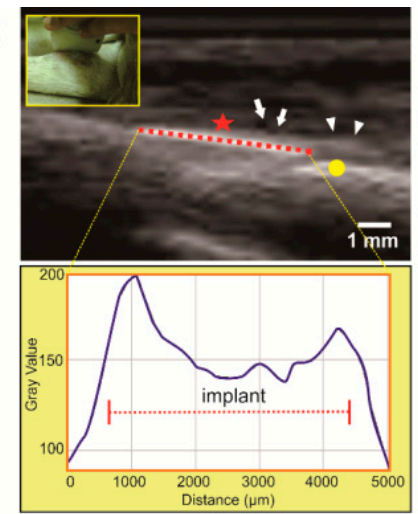

C

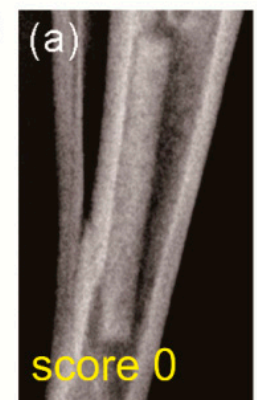

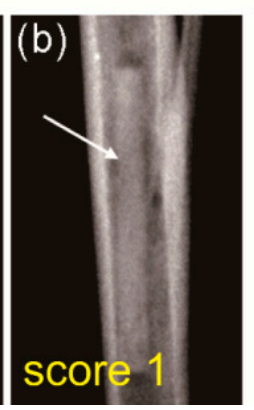
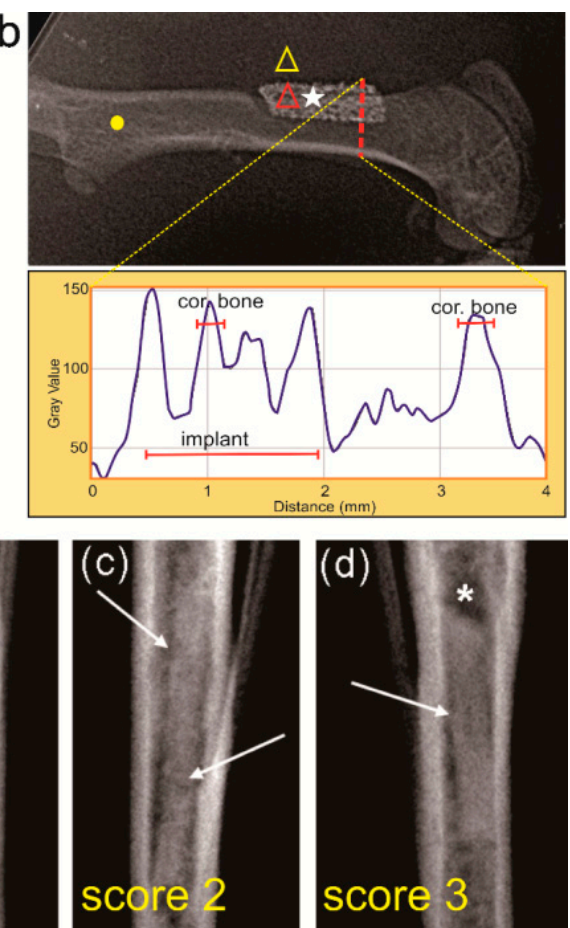

Figure 4. Qualitative and quantitative assessment of tissue-implant interaction: (a) ultrasonography (USG) image analysis of Fe-bioceramic plate in sheep as a way to quantitatively assess corrosion based on the reflected sound wave using ImageJ image processing software; (b) radiography-image analysis of porous Fe implant in a Sprague-Dawley rat using the same ImageJ software but based on the opacity of the X-ray image; (c) radiographic score system used for LANd442 Mg implant in New Zealand white rabbits over 4-10 weeks as another approach in qualitative assessment of bone tissue reaction and structure change of implant. Note: arrow tip $=$ new bone tissue around the implant, short arrow $=$ fluid around the implant, red star and white star- $1=$ implant, circle $=$ bone, red triangle $=$ implant, yellow triangle $=$ muscle, long arrows: $=$ structural loss, white star- $2=$ shape changes. Adapted with permission from Elsevier [51,61].

More recent diagnostic instruments used to assess the in-vivo corrosion of absorbable metals are Micro-Computed Tomography $(\mu \mathrm{CT}$ ) and Magnetic Resonance Imaging (MRI). $\mu \mathrm{CT}$ utilizes X-rays to produce $2 \mathrm{D}$ images and $3 \mathrm{D}$ reconstructed images based on the attenuation after passing through the target tissue. It was used to study the corrosion of a pure $\mathrm{Mg}$ pin implanted for 16 weeks in the femoral bone of rabbits (Figure 5a) [63], and pure Fe stent implanted in the tail vein of rats (Figure 5b) [58]. In MRI, a powerful magnetic field is used to expose and spin the protons, then a beam of radio wave is introduced to forcibly change the direction of the protons. Images are created based on the energy that the protons release to realign with the magnetic field once pulsing the radio wave has stopped [64]. Even though magnetic implants are usually avoided to be scanned under MRI, an Fe stent implanted in rabbit abdominal aorta was successfully imaged by this instrument despite the presence of artifacts (Figure 5c) [22]. However, it was shown that MRI has a modality to image tissue-implant interaction 
in better quality for absorbable $\mathrm{Mg}$ alloys, i.e., less artifacts, compared to that of inert metals such as titanium [65].

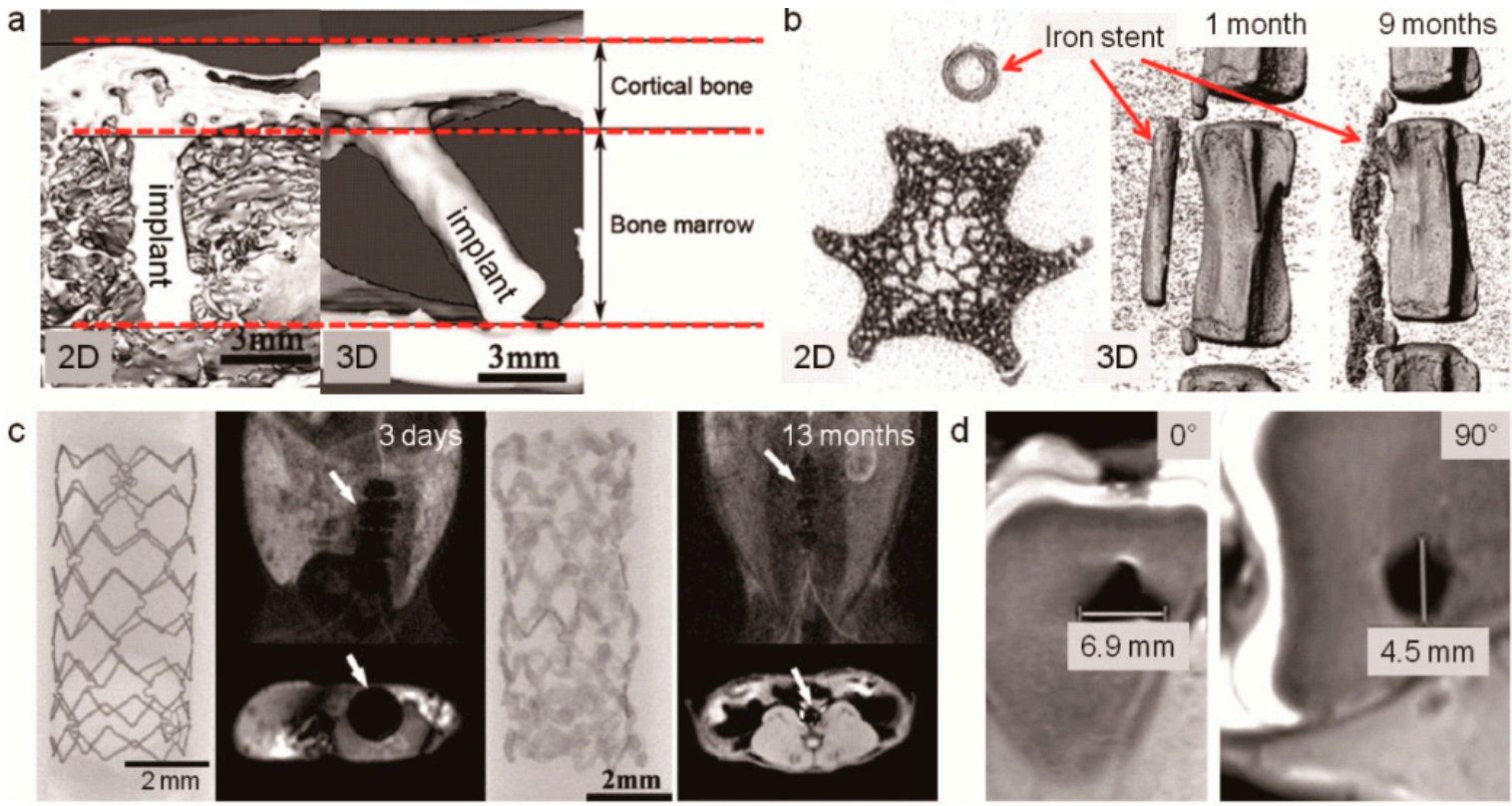

Figure 5. Tissue-implant interaction assessment: (a) Micro-Computed Tomography $(\mu \mathrm{CT})$ image of a high-purity $\mathrm{Mg}$ pin implanted in the femur of New Zealand white rabbits after 16 weeks enabling the visualization of implant morphological change both on the surface and the internal architecture and reaction of the attached hard tissue; (b) $\mu \mathrm{CT}$ image of pure Fe stent after 1 and 9 months implanted in tail veins of mice allowing a follow-up of detail morphological change of the stent during the corrosion process; (c) Magnetic Resonance Imaging (MRI) image of Fe stent after 3 days and 13 months implantation in the abdominal aorta of rabbit showing the detail structural change of the stent; (d) MRI image of Mg Herbert screw in chicken femoral bone showing a lesser artifact produced by absorbable metal implant than by inert implant. Adapted with permission from Elsevier and John Wiley and Sons $[22,58,63,65]$.

\subsection{Comparison of In-Vivo Corrosion Characterization Techniques}

In the quest for an ideal technique for monitoring the interaction between the absorbable metal implant and the surrounding tissue, i.e., changes on implant and the surrounding tissue due to corrosion, one may consider two facts: (1) corrosion is a time-dependent continuous phenomenon; (2) although it is a surface phenomenon, it is spatially continuous, i.e., slicing/segmenting the corroded implant would not provide information from the whole corroded part of the implant. Therefore, the ideal approach should provide real-time data while corrosion of the implant is taking place without inducing physical constraint on the animal. Additionally, the data should represent what is happening in all affected locations of the implant rather than just segments of it (being spatially continuous). The latter is especially important when the absorbable implant is foam-like and the corroded surfaces occupy a very significant volume of the implant. The common medical diagnostic tools and instruments available in most medical facilities can be used to assess in-vivo corrosion of absorbable metal implants. The objective of the assessment is to obtain maximum detailed information from limited number of samples, i.e., implants and animals, by using each instrument. Therefore, considering the unique capabilities and limitations of each technique (Table 2), it can be used as a complementary tool beside others to obtain information, e.g., images, required for a comprehensive analysis. Most of those techniques provide segmental (spatially discontinuous) offline information, i.e., imaging, whilst corrosion is a time-dependent process. Even though MRI and USG can provide 
real-time images, their continuous use for in-vivo corrosion monitoring does not seem to be feasible, especially when they primarily were meant to be used for medical purposes.

Table 2. Comparison of capabilities and limitations of common techniques for in-vivo corrosion assessment of absorbable metal implants.

\begin{tabular}{|c|c|c|}
\hline Technique & Capability & Limitation \\
\hline SEM and EDS & $\begin{array}{l}\text { Morphological imaging of retrieved implant } \\
\text { and on-the-spot semi-quantitative chemical } \\
\text { composition analysis }\end{array}$ & $\begin{array}{l}\text { Unable to image the internal } \\
\text { structure of the implant except on } \\
\text { the cross-section obtained from } \\
\text { cutting the sample }\end{array}$ \\
\hline FTIR, XPS, XRD & $\begin{array}{c}\text { Chemical composition analysis on the surface } \\
\text { of retrieved implant, determine } \\
\text { organic/inorganic compounds }\end{array}$ & $\begin{array}{l}\text { Cross-sectioning is needed for } \\
\text { sub-surface analysis }\end{array}$ \\
\hline Histology & $\begin{array}{l}\text { A gold standard for tissue-implant reaction } \\
\text { analysis, reveal cellular morphology at } \\
\text { micro-scale level and tissue reaction by using } \\
\text { contrast stain for specific targeted biomarkers }\end{array}$ & $\begin{array}{l}\text { An invasive procedure requiring } \\
\text { biopsy or animal sacrifice, requires a } \\
\text { large number of animals to obtain } \\
\text { acceptable statistical precision }\end{array}$ \\
\hline USG & $\begin{array}{l}\text { A gold standard for real-time soft tissue } \\
\text { imaging, non-invasive, image tissue } \\
\text { formation in } 2 \mathrm{D} \text {, and fluid-containing organ } \\
\text { in 3D (i.e., vesical urinary and blood vessel), } \\
\text { visual qualitative analysis sonograms }\end{array}$ & $\begin{array}{c}\text { Unable to image the internal } \\
\text { structure of hard implant nor hard } \\
\text { tissue }\end{array}$ \\
\hline X-ray radiography & $\begin{array}{l}\text { A gold standard for non-invasive hard tissue } \\
\text { imaging, produce 2D image of gross tissue } \\
\text { (combination of hard and soft tissue), image } \\
\text { nearly all biomaterials, similar to USG, } \\
\text { qualitative analysis by visual observation of } \\
\text { radiographs, quantitative analysis by means } \\
\text { of image processing software }\end{array}$ & $\begin{array}{c}\text { Require multiple images of } \\
\text { difference angles to assess one } \\
\text { implant, difficult to differentiate a } \\
\text { ceramic-based material from natural } \\
\text { bone matrix due to their similar } \\
\text { opacity, special precaution to handle } \\
\text { radiation effect }\end{array}$ \\
\hline$\mu \mathrm{CT}$ & $\begin{array}{c}\text { Enhanced capabilities of } X \text {-ray radiography } \\
\text { with possibility to generate a complete 3D } \\
\text { image, as a product of stacking discontinuous } \\
\text { 2D slices, of an implant and its surrounding } \\
\text { tissue }\end{array}$ & $\begin{array}{l}\text { A special preparation for animal } \\
\text { handling and requirement for } \\
\text { restraining the animal such as } \\
\text { general anesthesia is needed to } \\
\text { avoid motion during imaging }\end{array}$ \\
\hline MRI & $\begin{array}{c}\text { The most advanced non-invasive medical } \\
\text { diagnostic tool for real-time soft and hard } \\
\text { tissue imaging }\end{array}$ & $\begin{array}{l}\text { Unable to image magnetized } \\
\text { metallic implant, metallic implant } \\
\text { produces artifacts }\end{array}$ \\
\hline
\end{tabular}

\section{Real-Time In-Vivo Corrosion Monitoring}

In-vivo corrosion of metals is a continuous time-dependent process which cannot be perfectly investigated through the aforementioned medical-derived techniques, since they do not provide real time data corresponding to the continuous (non-segmented) geometry of the sample. In-vivo corrosion evaluation tools for absorbable metals should function based on the generation of metal and hydroxyl ions, electric current flow and hydrogen gas (for $\mathrm{Mg}$ ) all of which constitute the nature of corrosion phenomenon. The change of physical properties of the implant due to corrosion could also be detected by a kind of sensor. In addition, the body response to corrosion could be associated with a detectable change in biomarkers. The existing in-vivo approaches for investigating the corrosion of absorbable metal implants can be grouped into: electrochemical-based monitoring system, biosensor-based monitoring system, microdialysis-based monitoring system and biomarker-based monitoring system.

\subsection{Electrochemical-Based Monitoring System}

An electrochemical-based monitoring system basically measures the behavior of analyte in a heterogeneous environment. When an electrode is placed in an electrolyte solution, a phase boundary 
forms between the solid electrode and the bulk solution. The barriers between the two phases produces electron movement (electric current) to the electrode which can be converted and measured as electric potential (voltage). This system has two general types; amperometric sensor circuit and potentiostat circuit [66]. The amperometric sensor circuit has three electrodes namely the working electrode, reference electrode and counter electrode (Figure 6a). Over the past five years, several systems have been developed to study the behavior of absorbable metals during corrosion in real-time. By developing a set-up composed of a vascular bioreactor (with circulation of simulated body fluid to simulate the dynamic in-vivo condition) and an electrochemical cell (attached to a potentiostat), (Figure 6b) Wang et al. [39] investigated the corrosion of a Mg alloy in-situ.
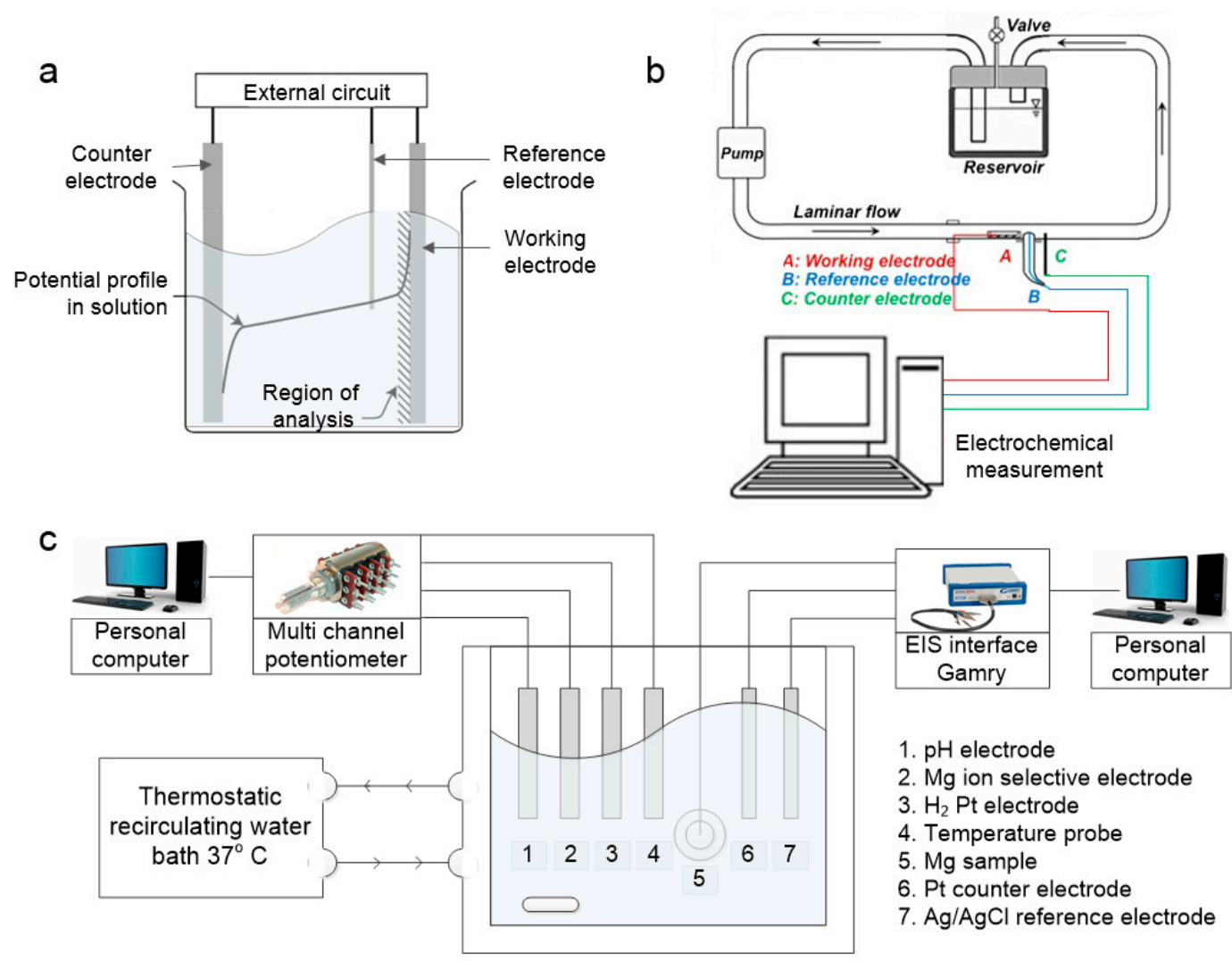

Figure 6. Electrochemical-based monitoring systems: (a) a three-electrode electrochemical cell of amperometric sensor; (b) an experimental setup to study the dynamic corrosion of an absorbable metal in-situ and in real time; (c) a corrosion characterization system instrument and cell configuration. Adapted with permission from Elsevier $[39,66,67]$.

Another electrochemical-based system was developed to monitor the real-time corrosion of $\mathrm{Mg}$, namely the corrosion characterization system [67]. This system (Figure 6c) consists of multiple electrochemical sensors such as capillary $\mathrm{pH}$ and $\mathrm{Mg}^{2+}$ sensors that measure the solution-soluble corrosion products of $\mathrm{Mg}$ oxidation in water, and an electrochemical impedance spectroscopy (EIS). The EIS monitors the changes in Faradaic and non-Faradaic impedances at the metal-solution interfaces at low and high-frequencies. The Faradaic impedance, shown in low frequencies spectrum, is generated due to the anodic and cathodic reactions, whilst the surface charging and occlusion by corrosion product or passivation can be monitored from the non-Faradaic impedances in the high frequencies spectrum [67]. Actually, the applicability of EIS has been found to be feasible for in-vivo measurements, such as to characterize the electrical bioimpedance of human lung tissue during the bronchoscopy procedure [68], and to monitor in-vivo corrosion monitoring and tissue discrimination in live mice [69]. However, Kuwabara et al. [70] noted that the EIS technique for in-vivo recording is limited by the electrode life as its quality and accuracy can change over time. 


\subsection{Sensor-Based Monitoring System}

The sensor-based monitoring system may have some overlaps with that of electrochemical-based. A set-up developed by Zhao et al. [71] can be put in this category. In this non-invasive set-up (Figure 7a), the real-time concentration of hydrogen gas is measured by a micro-sensor, and they used it to study the corrosion behavior of an Mg alloy in-vivo (Figure 7b). In spite of the low level of the permeated hydrogen through the skin $(30-400 \mu \mathrm{M})$, the sensor was able to detect it in a short response time of $30 \mathrm{~s}$. This was depicted in the 3D visualization of the hydrogen permeation (Figure 7c) [72]. More thorough understanding of the corrosion behavior of $\mathrm{Mg}$ was achieved using Inductively-Coupled Plasma Mass Spectrometry (ICP-MS) and XPS as complementary characterization techniques. It was found that presence of impurities contributed to the fast in-vivo corrosion of $\mathrm{Mg}$ samples [73]. The limitation of the introduced set-up is its dependence on hydrogen permeation through the skin, making it infeasible to monitor corrosion behavior of $\mathrm{Mg}$ implants located in deeper sites, e.g., plates implanted underneath the muscle and bone screws.
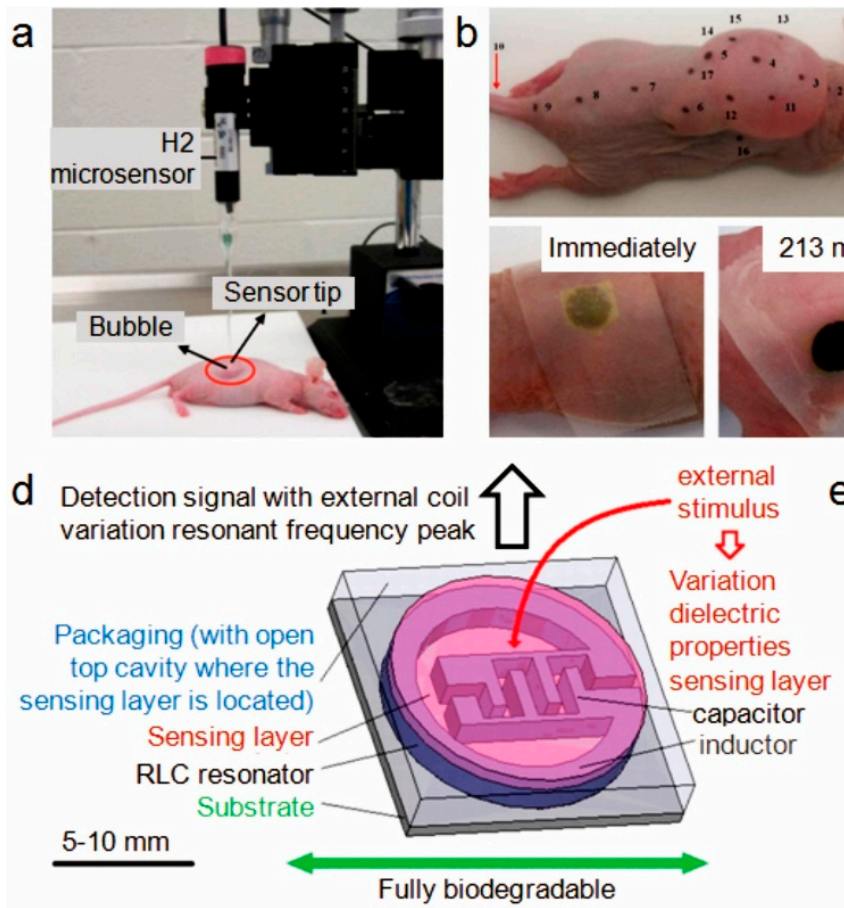
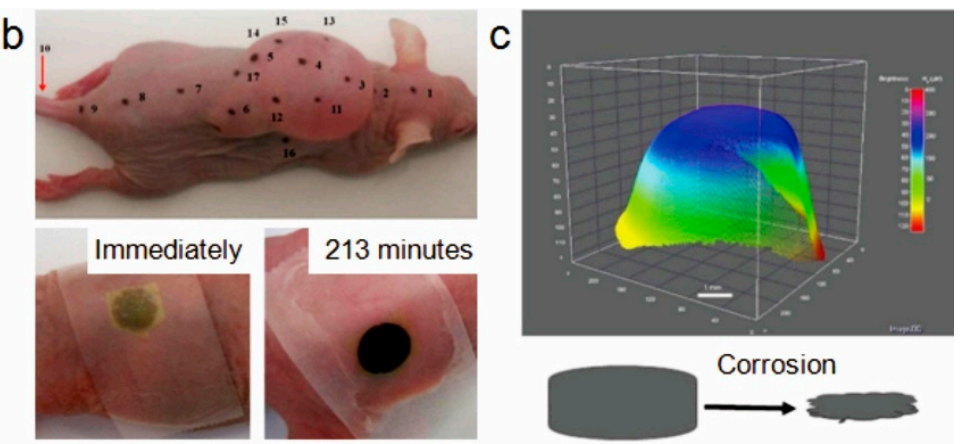

e

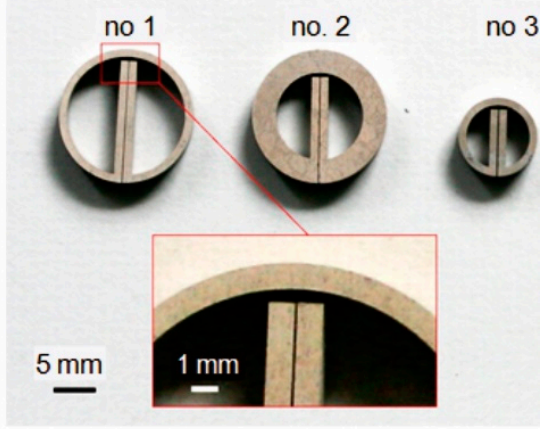

Figure 7. Sensor-based corrosion monitoring system: (a) hydrogen micro-sensor assembled on a micromanipulator for measuring hydrogen transdermally from a $\mathrm{Mg}$ alloy implanted subcutaneously in a mouse where the sensor tip is in a direct contact with the mouse skin; (b) photograph of an anaesthetized nude mouse with marked measurement points, and color development of thin film visual hydrogen sensor at two different observation times; (c) 3D reconstruction of the brightness change in the hydrogen sensor area at $213 \mathrm{~min}$ and associated volume change of the $\mathrm{Mg}$ implant; (d) design of a fully biodegradable sensor (wireless telemetry with inductive link); (e) resistor-inductor-capacitor (RLC) resonators made of absorbable materials. Adapted with permission from Elsevier and Springer Nature $[72,74,75]$. 
Considering the change in physical characteristics of an absorbable metal implant over time due to corrosion, Boutry et al. [76] developed a system from the metal itself (Figure 7d,e). It was a miniaturized wireless operation biodegradable radiofrequency-driven resistor-inductor-capacitor (RLC) resonator made of absorbable metals (Mg and its alloys, Fe and its alloys) and biodegradable conductive polymer composites (polycaprolactone-polypyrrole, polylactide-polypyrrole) [75]. They observed that the $\mathrm{Mg}$ alloy was the best metal to fabricate RLC resonators, as it possesses higher mechanical performance, high conductivity (high $Q$ ) and higher corrosion rate [76]. Further analyses are necessary to support the idea of using such a device for in-vivo corrosion monitoring of absorbable metal implants.

Another potential real-time in-vivo corrosion monitoring system can be developed by using a micro-needle biosensor. Li et al. [77] have designed, fabricated and characterized a micro-needle biosensor attached to a new smart catheter and equipped with LabVIEW data acquisition program that is capable of monitoring glucose and oxygen in patients with traumatic brain injuries. A similar technique was used on an invasive needle-type oxygen micro-sensor (microelectrode) for real-time monitoring of glucose in the brain [78]. The microelectrodes were made from a needle-type $\mathrm{Pt} / \mathrm{C}$ fiber and a gold coated $\mathrm{W}$-Au needle $\left(50 \mu \mathrm{m}\right.$ diameter, $2 \mathrm{~mm}$ length, $3.147 \mathrm{~mm}^{2}$ of surface area). The robustness of the micro-needle biosensor including the response time, accuracy, precision and long-term stability was confirmed by Kojima et al. [79] when used as a minimally invasive glucose monitoring system. However, the applicability of micro-needle biosensor for in vivo corrosion monitoring of absorbable metal implants needs to be confirmed [80].

\subsection{Microdialysis-Based Monitoring System}

Microdialysis can be used for real-time assessment of both in-vivo and in-vitro corrosion of target substrates. It is based upon the detection of the released metal ions. It has been used to study the effect of pure $\mathrm{Mg}$ corrosion on the neighboring tissue in an isolated perfused bovine udder model (ex-vivo) [81]. The biocompatibility of the implant was evaluated by $\mathrm{PGE}_{2}$ and TNF- $\alpha$ used as inflammation indicators. They suggested that the concentration of $\mathrm{Mg}$ ions during corrosion and the biocompatibility of the pure $\mathrm{Mg}$ was acceptable. Although they have managed to evaluate the in-vivo behavior of the implant, the results have not yet been measured in real time. In another study, Ulrich et al. [82] investigated the corrosion behavior of $\mathrm{Mg}$ alloys using a set up based upon a micro-flow capillary $(\mu \mathrm{FC})$ that was coupled online to an inductively coupled plasma mass spectrometer (ICP-MS) by a flow injection analyzing system (FIAS) (Figure 8a). It was suspected that the generated hydrogen bubbles inhibited sufficient distribution of the released elements in the circulating solution within the capillary, possibly leading to inaccurate results. Natasha et al. [83] developed an online monitoring system which consisted of a microdialysis probe (to collect the fluid surrounding the Mg implant) and a fabric-based electrochemical device (FED) (as a catalytic Mg biosensor), both of which were connected to a potentiostat (Figure 8b). The set-up indicated a pseudo-linear response of concentration with ion selectivity as high as $99 \%$ and high temporal resolution with little sampling time and volume of the fluid sample as low as $3 \mu \mathrm{L}$. This system could be further enhanced as a possible alternative for real time in-vivo assessment of absorbable $\mathrm{Mg}$ implants.

\subsection{Biomarker-Based Monitoring System}

As the absorbable metal implant interacts with the surrounding tissue, biological responses such as cell proliferation and systematic cellular migration are generated. Differentiation and proliferation of cells are marked by particular types of biochemical substrates, e.g., hormones, growth factors and other substrates released in the extracellular fluid. The substrates are used by particular cells for each body event in the course of cellular communication [84,85]. It is possible to take advantage of these substrates as biomarkers to monitor the in-vivo corrosion process of absorbable metals. Great potential sources of the biomarkers are body fluids which can be collected from the animal's body either non-invasively, e.g., saliva, urine, milk and sweat, or invasively, e.g., cerebrospinal fluid and blood. Immunoassay-based analysis, e.g., enzyme-linked immunosorbent assay, enzyme immunoassay and radio immunoassay 
can be performed to study the biomarkers. Different types of biomaterials can induce different trends of released growth factor from the microenvironment. For example, osteoblast cells release a higher concentration of transforming growth factor- $\beta 1$ (TGF- $\beta 1$ ) after interacting with acrylic bone cement than that when they interact with bio-inert metal-based bio-inert implants such as cobalt chromium and titanium $[86,87]$. Therefore, such biomarkers can be potentially employed as markers to monitor the corrosion of absorbable metal implants.

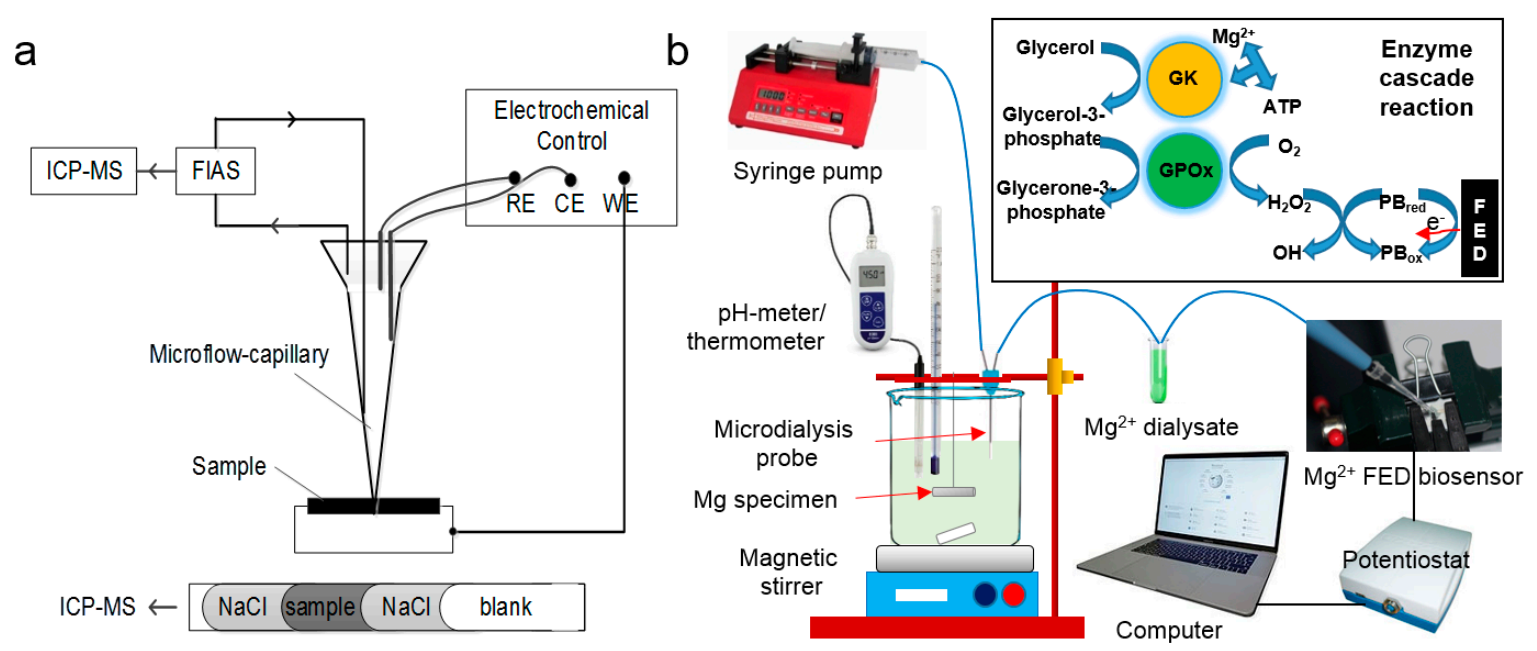

Figure 8. Experimental setup of: (a) micro-flow-capillary-coupled Inductively Coupled Plasma Mass Spectrometer (ICP-MS); (b) coupled microdialysis probe-fabric-based electrochemical device (FED) biosensor connected to a potentiostat (inset: dialysate is dropped at the reaction region of the biosensor that was immobilized with the GK and GPOx enzymes to detect $\mathrm{Mg}^{2+}$ ions via enzymes cascade reaction). Adapted with permission from Elsevier and Springer Nature [82,83].

\subsection{Comparison of Real-Time In-Vivo Corrosion Monitoring Systems}

Understanding the fundamentals of in-vivo corrosion of absorbable metal implants requires advanced techniques capable of monitoring the process in real-time. Currently, researchers are facing challenges in correlating the corrosion behavior of absorbable metals assessed in the in-vitro setting with that observed in the in-vivo condition. For instance, the optimized in-vitro corrosion rate of a well-designed alloy is often not replicated when tested in animal experiments. The current techniques utilized to quantitatively measure in-vivo corrosion parameters are limited to provide rather temporal and segmental information. The available potential techniques for real-time in-vivo corrosion monitoring offers some interesting capabilities but also some limitations (Table 3). Nevertheless, an optimal hybrid technique of sensor or sampling probes and data acquisition systems should be possible to develop. An ideal sensor or probe should be a minimum invasive device, such as micro-needle biosensor and microdialysis probe, and capable to detect multiple corrosion parameters, such as concentration of metal ions, hydrogen gas volume and electrical potential. A robust data acquisition and processing device is then necessary to collect and analyze the raw data and present them in terms of corrosion rate continuously. A data analysis algorithm should be developed to enable automatic processing with minimum human interference. 
Table 3. Comparison of capabilities and limitations of available systems for real-time in-vivo corrosion monitoring of absorbable metal implants.

\begin{tabular}{|c|c|c|}
\hline Technique & Capability & Limitation \\
\hline $\begin{array}{l}\text { Electrochemical-based } \\
\text { monitoring system }\end{array}$ & $\begin{array}{l}\text { Quantitatively measure corrosion rate and } \\
\text { electrochemical properties of corroded } \\
\text { surface in short-time (accelerated process) }\end{array}$ & $\begin{array}{l}\text { Unable to perform continuous in-vivo } \\
\text { corrosion measurement due to limited } \\
\text { electrode life or performance }\end{array}$ \\
\hline $\begin{array}{c}\text { Sensor-based } \\
\text { monitoring system }\end{array}$ & $\begin{array}{l}\text { Accurately measure certain corrosion } \\
\text { parameters using specific sensors, e.g., } \mathrm{H}_{2} \\
\text { sensor, } \mathrm{Mg} \text { ion sensor, possible use for } \\
\text { real-time and continuous in-vivo } \\
\text { corrosion monitoring as the sensor is } \\
\text { connected to a data acquisition device }\end{array}$ & $\begin{array}{l}\text { Requires special signal processing } \\
\text { and/or image processing algorithm to } \\
\text { process the raw data to represent the } \\
\text { corrosion rate parameter }\end{array}$ \\
\hline $\begin{array}{l}\text { Microdialysis-based } \\
\text { monitoring system }\end{array}$ & $\begin{array}{l}\text { Potential to be developed into online } \\
\text { monitoring when microdialysis probe is } \\
\text { connected to a data acquisition device }\end{array}$ & $\begin{array}{l}\text { Limited probe life/performance due to } \\
\text { possible biofouling, challenging } \\
\text { calibration procedure }\end{array}$ \\
\hline $\begin{array}{l}\text { Biomarker-based } \\
\text { monitoring system }\end{array}$ & $\begin{array}{c}\text { Indirect in-vivo corrosion monitoring } \\
\text { based on biomarkers in body fluid } \\
\text { assessment }\end{array}$ & $\begin{array}{l}\text { Low accuracy due to indirect } \\
\text { relationship with the corroded } \\
\text { implant }\end{array}$ \\
\hline
\end{tabular}

\section{Conclusions}

Correlating the in-vivo corrosion test results with those of the in-vitro tests is amongst the utmost challenges of the absorbable metal world. The challenge of discrepancy between the corrosion test results also applies to materials with identical chemical compositions but with different structures and processing histories. Fortunately, developing standard guides for absorbable metals has begun, and it is progressing well. As such, researchers can tackle the remaining challenges, thus promoting a faster clinical translation to meet the patients' needs. ASTM has already published two standards for in-vitro corrosion and metallurgical evaluation of absorbable metals. However, the standards addressing the in-vivo corrosion and biological aspects are being developed by ISO. For the time being, the approaches to study the in-vivo corrosion of absorbable metals are adopted from those used for inert biomaterials, e.g., histology, implant retrieval and radiography imaging. These methods face limitations such as giving spatially discontinuous (segmented) offline results. Therefore, they do not perfectly reflect the corrosion of metals. Development of novel approaches for real-time monitoring and characterization of in-vivo corrosion should be considered as a leading direction for future works.

Author Contributions: All authors contributed to original draft preparation, revision and editing.

Funding: This work was funded by the Natural Sciences and Engineering Research Council of Canada (NSERC) through the Discovery Grant \#638165 (Hendra Hermawan, Reza Alavi), the Indonesia Ministry of Research, Technology and Higher Education (Ristekdikti) through the Overseas Collaboration and International Publications Grant \#1570/IT3.11/PN/2018 (Mokhamad Fakhrul Ulum), and the University of Brunei Darussalam through the Faculty Research Grant \#2019 (Wahyu Caesarendra).

Conflicts of Interest: The author declares no conflict of interest.

\section{References}

1. ASTM F3160-16 Standard Guide for Metallurgical Characterization of Absorbable Metallic Materials for Medical Implants; ASTM International: West Conshohocken, PA, USA, 2016.

2. Zheng, Y.; Gu, X.; Witte, F. Biodegradable metals. Mater. Sci. Eng. R Rep. 2014, 77, 1-34. [CrossRef]

3. Agarwal, S.; Curtin, J.; Duffy, B.; Jaiswal, S. Biodegradable magnesium alloys for orthopaedic applications: A review on corrosion, biocompatibility and surface modifications. Mater. Sci. Eng. C 2016, 68, $948-963$. [CrossRef] [PubMed]

4. Hermawan, H. Updates on the research and development of absorbable metals for biomedical applications. Prog. Biomater. 2018, 7, 93-110. [PubMed] 
5. Cui, L.-Y.; Gao, S.-D.; Li, P.-P.; Zeng, R.-C.; Zhang, F.; Li, S.-Q.; Han, E.-H. Corrosion resistance of a self-healing micro-arc oxidation/polymethyltrimethoxysilane composite coating on magnesium alloy AZ31. Corros. Sci. 2017, 118, 84-95. [CrossRef]

6. Wang, H.; Zheng, Y.; Liu, J.; Jiang, C.; Li, Y. In vitro corrosion properties and cytocompatibility of Fe-Ga alloys as potential biodegradable metallic materials. Mater. Sci. Eng. C 2017, 71, 60-66. [CrossRef]

7. Haude, M.; Ince, H.; Kische, S.; Abizaid, A.; Tölg, R.; Alves, L.P.; Van Mieghem, N.; Verheye, S.; Von Birgelen, C.; Christiansen, E. Sustained safety and clinical performance of a drug-eluting absorbable metal scaffold up to 24 months: Pooled outcomes of biosolve-ii and biosolve-iii. EuroIntervention 2017, 13, 432-439.

8. Biber, R.; Pauser, J.; Brem, M.; Bail, H.J. Bioabsorbable metal screws in traumatology: A promising innovation. Trauma Case Rep. 2017, 8, 11-15. [CrossRef]

9. Li, X.; Liu, X.; Wu, S.; Yeung, K.; Zheng, Y.; Chu, P.K. Design of magnesium alloys with controllable degradation for biomedical implants: From bulk to surface. Acta Biomater. 2016, 45, 2-30. [CrossRef]

10. Mostaed, E.; Sikora-Jasinska, M.; Drelich, J.W.; Vedani, M. Zinc-based alloys for degradable vascular stent applications. Acta Biomater. 2018, 71, 1-23. [CrossRef] [PubMed]

11. He, J.; He, F.-L.; Li, D.-W.; Liu, Y.-L.; Liu, Y.-Y.; Ye, Y.-J.; Yin, D.-C. Advances in fe-based biodegradable metallic materials. Rsc Adv. 2016, 6, 112819-112838. [CrossRef]

12. Vojtech, D.; Kubasek, J.; Capek, J.; Pospisilova, I. Comparative mechanical and corrosion studies on magnesium, zinc and iron alloys as biodegradable metals. Mater. Technol 2015, 49, 877-882.

13. Kraus, T.; Moszner, F.; Fischerauer, S.; Fiedler, M.; Martinelli, E.; Eichler, J.; Witte, F.; Willbold, E.; Schinhammer, M.; Meischel, M. Biodegradable Fe-based alloys for use in osteosynthesis: Outcome of an in vivo study after 52 weeks. Acta Biomater. 2014, 10, 3346-3353. [CrossRef] [PubMed]

14. Drynda, A.; Hassel, T.; Bach, F.W.; Peuster, M. In vitro and in vivo corrosion properties of new iron-manganese alloys designed for cardiovascular applications. J. Biomed. Mater. Res. Part B Appl. Biomater. 2015, 103, 649-660. [CrossRef] [PubMed]

15. Lin, W.; Qin, L.; Qi, H.; Zhang, D.; Zhang, G.; Gao, R.; Qiu, H.; Xia, Y.; Cao, P.; Wang, X. Long-term in vivo corrosion behavior, biocompatibility and bioresorption mechanism of a bioresorbable nitrided iron scaffold. Acta Biomater. 2017, 54, 454-468. [CrossRef]

16. Shi, Y.-J.; Pei, J.; Zhang, J.; Niu, J.-L.; Zhang, H.; Guo, S.-R.; Li, Z.-H.; Yuan, G.-Y. Enhanced corrosion resistance and cytocompatibility of biodegradable mg alloys by introduction of $\mathrm{Mg}(\mathrm{OH})_{2}$ particles into poly (L-lactic acid) coating. Sci. Rep. 2017, 7, 41796. [CrossRef] [PubMed]

17. Liu, J.; Wang, P.; Chu, C.-C.; Xi, T. A novel biodegradable and biologically functional arginine-based poly (ester urea urethane) coating for $\mathrm{Mg}-\mathrm{Zn}-\mathrm{Y}-\mathrm{Nd}$ alloy: Enhancement in corrosion resistance and biocompatibility. J. Mater. Chem. B 2017, 5, 1787-1802. [CrossRef]

18. Čapek, J.; Stehlíková, K.; Michalcová, A.; Msallamová, Š.; Vojtěch, D. Microstructure, mechanical and corrosion properties of biodegradable powder metallurgical Fe-2 $\mathrm{wt} \% x(x=\mathrm{Pd}, \mathrm{Ag}$ and $\mathrm{C})$ alloys. Mater. Chem. Phys. 2016, 181, 501-511. [CrossRef]

19. Hufenbach, J.; Wendrock, H.; Kochta, F.; Kühn, U.; Gebert, A. Novel biodegradable Fe-Mn-Cs alloy with superior mechanical and corrosion properties. Mater. Lett. 2017, 186, 330-333. [CrossRef]

20. Sotoudehbagha, P.; Sheibani, S.; Khakbiz, M.; Ebrahimi-Barough, S.; Hermawan, H. Novel antibacterial biodegradable Fe-Mn-Ag alloys produced by mechanical alloying. Mater. Sci. Eng. C 2018, 88, 88-94. [CrossRef]

21. Sikora-Jasinska, M.; Chevallier, P.; Turgeon, S.; Paternoster, C.; Mostaed, E.; Vedani, M.; Mantovani, D. Long-term in vitro degradation behaviour of fe and $\mathrm{Fe} / \mathrm{Mg}_{2} \mathrm{Si}$ composites for biodegradable implant applications. Rsc Adv. 2018, 8, 9627-9639. [CrossRef]

22. Lin, W.-J.; Zhang, D.-Y.; Zhang, G.; Sun, H.-T.; Qi, H.-P.; Chen, L.-P.; Liu, Z.-Q.; Gao, R.-L.; Zheng, W. Design and characterization of a novel biocorrodible iron-based drug-eluting coronary scaffold. Mater. Des. 2016, 91, 72-79. [CrossRef]

23. Huang, T.; Cheng, Y.; Zheng, Y. In vitro studies on silver implanted pure iron by metal vapor vacuum arc technique. Colloids Surf. B Biointerfaces 2016, 142, 20-29. [CrossRef]

24. Yusop, A.H.M.; Daud, N.M.; Nur, H.; Kadir, M.R.A.; Hermawan, H. Controlling the degradation kinetics of porous iron by poly (lactic-co-glycolic acid) infiltration for use as temporary medical implants. Sci. Rep. 2015, 5, 11194. [CrossRef] 
25. Cysewska, K.; Macía, L.F.; Jasiński, P.; Hubin, A. Tailoring the electrochemical degradation of iron protected with polypyrrole films for biodegradable cardiovascular stents. Electrochim. Acta 2017, 245, 327-336. [CrossRef]

26. Li, T.; He, Y.; Zhou, J.; Tang, S.; Yang, Y.; Wang, X. Effects of scandium addition on biocompatibility of biodegradable Mg-1.5Zn-0.6Zr alloy. Mater. Lett. 2018, 125, 200-202. [CrossRef]

27. Hofstetter, J.; Martinelli, E.; Weinberg, A.M.; Becker, M.; Mingler, B.; Uggowitzer, P.J.; Löffler, J.F. Assessing the degradation performance of ultrahigh-purity magnesium in vitro and in vivo. Corros. Sci. 2015, 91, 29-36. [CrossRef]

28. Qu, S.; Xia, J.; Yan, J.; Wu, H.; Wang, H.; Yi, Y.; Zhang, X.; Zhang, S.; Zhao, C.; Chen, Y. In vivo and in vitro assessment of the biocompatibility and degradation of high-purity $\mathrm{Mg}$ anastomotic staples. J. Biomater. Appl. 2017, 31, 1203-1214. [CrossRef]

29. Zander, D.; Zumdick, N.A. Influence of $\mathrm{Ca}$ and Zn on the microstructure and corrosion of biodegradable Mg-Ca-Zn alloys. Corros. Sci. 2015, 93, 222-233. [CrossRef]

30. Mao, L.; Chen, J.; Zhang, X.; Kwak, M.; Wu, Y.; Fan, R.; Zhang, L.; Pei, J.; Yuan, G.; Song, C. A promising biodegradable magnesium alloy suitable for clinical vascular stent application. Sci. Rep. 2017, 7, 46343. [CrossRef] [PubMed]

31. Hiromoto, S.; Inoue, M.; Taguchi, T.; Yamane, M.; Ohtsu, N. In vitro and in vivo biocompatibility and corrosion behaviour of a bioabsorbable magnesium alloy coated with octacalcium phosphate and hydroxyapatite. Acta Biomater. 2015, 11, 520-530. [CrossRef]

32. Witecka, A.; Yamamoto, A.; Idaszek, J.; Chlanda, A.; Święszkowski, W. Influence of biodegradable polymer coatings on corrosion, cytocompatibility and cell functionality of $\mathrm{Mg}-2.0 \mathrm{Zn}-0.98 \mathrm{Mn}$ magnesium alloy. Colloids Surf. B Biointerfaces 2016, 144, 284-292. [CrossRef]

33. Su, Y.; Li, D.; Su, Y.; Lu, C.; Niu, L.; Lian, J.; Li, G. Improvement of the biodegradation property and biomineralization ability of magnesium-hydroxyapatite composites with dicalcium phosphate dihydrate and hydroxyapatite coatings. Acs Biomater. Sci. Eng. 2016, 2, 818-828. [CrossRef]

34. Patil, A.J.; Jackson, O.; Fulton, L.B.; Hong, D.; Desai, P.A.; Kelleher, S.A.; Chou, D.-T.; Tan, S.; Kumta, P.N.; Beniash, E. Anticorrosive self-assembled hybrid alkylsilane coatings for resorbable magnesium metal devices. Acs Biomater. Sci. Eng. 2017, 3, 518-529. [CrossRef]

35. Sanchez, A.H.M.; Luthringer, B.J.; Feyerabend, F.; Willumeit, R. Mg and mg alloys: How comparable are in vitro and in vivo corrosion rates? A review. Acta Biomater. 2015, 13, 16-31. [CrossRef] [PubMed]

36. Bowen, P.K.; Drelich, A.; Drelich, J.; Goldman, J. Rates of in vivo (arterial) and in vitro biocorrosion for pure magnesium. J. Biomed. Mater. Res. Part A 2015, 103, 341-349. [CrossRef]

37. Johnston, K.A.; Westover, A.J.; Rojas-Pena, A.; Buffington, D.A.; Pino, C.J.; Smith, P.L.; Humes, H.D. Development of a wearable bioartificial kidney using the bioartificial renal epithelial cell system (BRECS). J. Tissue Eng. Regen. Med. 2017, 11, 3048-3055. [CrossRef]

38. Myrissa, A.; Agha, N.A.; Lu, Y.; Martinelli, E.; Eichler, J.; Szakacs, G.; Kleinhans, C.; Willumeit-Römer, R.; Schäfer, U.; Weinberg, A.-M. In vitro and in vivo comparison of binary Mg alloys and pure Mg. Mater. Sci. Eng. C 2016, 61, 865-874. [CrossRef]

39. Wang, J.; Jang, Y.; Wan, G.; Giridharan, V.; Song, G.-L.; Xu, Z.; Koo, Y.; Qi, P.; Sankar, J.; Huang, N.; et al. Flow-induced corrosion of absorbable magnesium alloy: In-situ and real-time electrochemical study. Corros. Sci. 2016, 104, 277-289. [CrossRef] [PubMed]

40. Hayes, B.K. Standardized guidance for the preclinical evaluation of absorbable metal implants. In Magnesium Technology 2016; Springer: Cham, Switzerland, 2016; pp. 357-359.

41. ASTM F3268 Standard Guide for in vitro Degradation Testing of Absorbable Metals; ASTM International: West Conshohocken, PA, USA, 2018.

42. ISO/DTS 37137-1 Biological Evaluation of Medical Devices-Part 1: Guidance for Absorbable Implants; International Organization for Standardization: Genève, Switzerland, 2018.

43. ISO/DTR 37137-2 Biological Evaluation of Medical Devices-Part 2: Guidance for Absorbable Metal Implants; International Organization for Standardization: Genève, Switzerland, 2018.

44. KyungáKim, Y. Biomolecular strategies to modulate the macrophage response to implanted materials. J. Mater. Chem. B 2016, 4, 1600-1609.

45. Yu, T.; Tutwiler, V.J.; Spiller, K. The role of macrophages in the foreign body response to implanted biomaterials. In Biomaterials in Regenerative Medicine and the Immune System; Springer: Cham, Switzerland, 2015; pp. 17-34. 
46. Witte, F.; Eliezer, A. Biodegradable metals. In Degradation of Implant Materials; Eliaz, N., Ed.; Springer New York: New York, NY, USA, 2012; pp. 93-109.

47. Xin, Y.; Huo, K.; Tao, H.; Tang, G.; Chu, P.K. Influence of aggressive ions on the degradation behavior of biomedical magnesium alloy in physiological environment. Acta Biomater. 2008, 4, 2008-2015. [CrossRef]

48. Yamamoto, A.; Hiromoto, S. Effect of inorganic salts, amino acids and proteins on the degradation of pure magnesium in vitro. Mater. Sci. Eng. C 2009, 29, 1559-1568. [CrossRef]

49. Xu, L.; Zhu, S.; Huang, N.; Li, X.; Zhang, Y. The corrosion of pure iron in five different mediums. Sheng $W u$ Yi Xue Gong Cheng Xue Za Zhi 2009, 26, 783-786.

50. Liu, C.; Xin, Y.; Tian, X.; Chu, P.K. Degradation susceptibility of surgical magnesium alloy in artificial biological fluid containing albumin. J. Mater. Res. 2007, 22, 1806-1814. [CrossRef]

51. Paramitha, D.; Ulum, M.F.; Purnama, A.; Wicaksono, D.H.B.; Noviana, D.; Hermawan, H. 2-Monitoring degradation products and metal ions in vivo. In Monitoring and Evaluation of Biomaterials and Their Performance In Vivo; Narayan, R.J., Ed.; Woodhead Publishing: Cambridge, UK, 2017; pp. 19-44.

52. Ulum, M.F.; Nasution, A.K.; Yusop, A.H.; Arafat, A.; Kadir, M.R.A.; Juniantito, V.; Noviana, D.; Hermawan, H. Evidences of in vivo bioactivity of Fe-bioceramic composites for temporary bone implants. J. Biomed. Mater. Res. Part B Appl. Biomater. 2015, 103, 1354-1365. [CrossRef] [PubMed]

53. Tan, L.; Wang, Q.; Lin, X.; Wan, P.; Zhang, G.; Zhang, Q.; Yang, K. Loss of mechanical properties in vivo and bone-implant interface strength of AZ31B magnesium alloy screws with Si-containing coating. Acta Biomater. 2014, 10, 2333-2340. [CrossRef]

54. Nasution, A.K.; Ulum, M.F.; Kadir, M.R.A.; Hermawan, H. Mechanical and corrosion properties of partially degradable bone screws made of pure iron and stainless steel 3161 by friction welding. Sci. China Mater. 2018, 61, 593-606. [CrossRef]

55. Lee, J.-W.; Han, H.-S.; Han, K.-J.; Park, J.; Jeon, H.; Ok, M.-R.; Seok, H.-K.; Ahn, J.-P.; Lee, K.E.; Lee, D.-H.; et al. Long-term clinical study and multiscale analysis of in vivo biodegradation mechanism of $\mathrm{Mg}$ alloy. Proc. Natl. Acad. Sci. USA 2016, 113, 716-721. [CrossRef] [PubMed]

56. Turyanskaya, A.; Rauwolf, M.; Grünewald, A.T.; Meischel, M.; Stanzl-Tschegg, S.; Löffler, F.J.; Wobrauschek, P.; Weinberg, M.A.; Lichtenegger, C.H.; Streli, C. $\mu$ XRF elemental mapping of bioresorbable magnesium-based implants in bone. Materials 2016, 9, 811. [CrossRef]

57. Paramitha, D.; Estuningsih, S.; Noviana, D.; Ulum, M.; Hermawan, H. Distribution of Fe-based degradable materials in mice skeletal muscle. Eur. Cells Mater. 2013, 26, 55.

58. Mueller, P.P.; Arnold, S.; Badar, M.; Bormann, D.; Bach, F.W.; Drynda, A.; Meyer-Lindenberg, A.; Hauser, H.; Peuster, M. Histological and molecular evaluation of iron as degradable medical implant material in a murine animal model. J. Biomed. Mater. Res. Part A 2012, 100, 2881-2889. [CrossRef]

59. Ulum, M.; Arafat, A.; Noviana, D.; Yusop, A.; Nasution, A.; Kadir, M.A.; Hermawan, H. In vitro and in vivo degradation evaluation of novel iron-bioceramic composites for bone implant applications. Mater. Sci. Eng. C 2014, 36, 336-344. [CrossRef] [PubMed]

60. Noviana, D.; Paramitha, D.; Ulum, M.F.; Hermawan, H. The effect of hydrogen gas evolution of magnesium implant on the postimplantation mortality of rats. J. Orthop. Transl. 2016, 5, 9-15. [CrossRef]

61. Ullmann, B.; Reifenrath, J.; Dziuba, D.; Seitz, J.-M.; Bormann, D.; Meyer-Lindenberg, A. In vivo degradation behavior of the magnesium alloy LANd442 in rabbit tibiae. Materials 2011, 4, 2197-2218. [CrossRef]

62. Reifenrath, J.; Krause, A.; Bormann, D.; Von Rechenberg, B.; Windhagen, H.; Meyer-Lindenberg, A. Profound differences in the in-vivo-degradation and biocompatibility of two very similar rare-earth containing Mg-alloys in a rabbit model. Materialwissenschaft und Werkstofftechnik 2010, 41, 1054-1061. [CrossRef]

63. Cheng, P.; Zhao, C.; Han, P.; Ni, J.; Zhang, S.; Zhang, X.; Chai, Y. Site-dependent osseointegration of biodegradable high-purity magnesium for orthopedic implants in femoral shaft and femoral condyle of new zealand rabbits. J. Mater. Sci. Technol. 2016, 32, 883-888. [CrossRef]

64. National Institute of Biomedical Imaging and Bioengineering (NIBIB). Magnetic Resonance Imaging (MRI). Available online: https://www.nibib.nih.gov/science-education/science-topics/magnetic-resonance-imagingmri (accessed on 25 April 2019).

65. Sonnow, L.; Könneker, S.; Vogt, P.M.; Wacker, F.; von Falck, C. Biodegradable magnesium herbert screw-image quality and artifacts with radiography, CT and MRI. BMC Med. Imaging 2017, 17, 16. [CrossRef]

66. Franklin, R.K. In Vivo Electrochemical Sensors. Ph.D. Thesis, The University of Michigan, Ann Arbor, MI, USA, 2010. 
67. Doepke, A.; Kuhlmann, J.; Guo, X.; Voorhees, R.T.; Heineman, W.R. A system for characterizing Mg corrosion in aqueous solutions using electrochemcal sensors and impedance spectroscopy. Acta Biomater. 2013, 9, 9211-9219. [CrossRef] [PubMed]

68. Sanchez, B.; Vandersten, G.; Martin, I.; Castillo, D.; Torrego, A.; Riu, P.J.; Schoukens, J.; Bragos, R. In vivo electrical bioimpedance characterization of human lung tissue during the bronschoscopy proseduce. A feasibility study. Med Eng. Phys. 2013, 35, 949-957. [CrossRef]

69. Williams, B.J. Applications of Electrochemical Impedance Spectroscopy In In Vivo Corrosion Monitoring and Tissue Discrimination. Master's Thesis, University of Cincinnati, Cincinnati, OH, USA, 2011.

70. Kuwabara, M.; Tashiro, H.; Terasawa, Y.; Nakano, Y.; Yoshimura, Y.; Osawa, K.; Noda, T.; Tokuda, T.; Ohta, J. Applications of electrochemical impedance spectroscopy in in vivo corrosion monitoring and tissue discrimination. Sens. Mater. 2017, 29, 1689-1702.

71. Zhao, D.; Wang, T.; Kuhlmann, J.; Dong, Z.; Chen, S.; Joshi, M.; Salunke, P.; Shanov, V.N.; Hong, D.; Kumta, P.N.; et al. In vivo monitoring the biodegradation of magnesium alloys with an electrochemical $\mathrm{H}_{2}$ sensor. Acta Biomater. 2016, 36, 361-368. [CrossRef]

72. Zhao, D.; Wang, T.; Hoagland, W.; Benson, D.; Dong, Z.; Chen, S.; Chou, D.-T.; Hong, D.; Wu, J.; Kumta, P.N. Visual $\mathrm{H}_{2}$ sensor for monitoring biodegradation of magnesium implants in vivo. Acta Biomater. 2016, 45, 399-409. [CrossRef] [PubMed]

73. Zhao, D.; Wang, T.; Nahan, K.; Guo, X.; Zhang, Z.; Dong, Z.; Chen, S.; Chou, D.-T.; Hong, D.; Kumta, P.N.; et al. In vivo characterization of magnesium alloy biodegradation using electrochemical $\mathrm{H}_{2}$ monitoring, ICP-MS, and XPS. Acta Biomater. 2017, 50, 556-565. [CrossRef]

74. Zhao, D.; Wang, T.; Guo, X.; Kuhlmann, J.; Doepke, A.; Dong, Z.; Shanov, V.N.; Heineman, W.R. Monitoring biodegradation of magnesium implants with sensors. JOM 2016, 68, 1204-1208. [CrossRef]

75. Boutry, C.M.; Chandrahalim, H.; Streit, P.; Schinhammer, M.; Hänzi, A.C.; Hierold, C. Towards biodegradable wireless implants. Philos. Trans. R. Soc. A Math. Phys. Eng. Sci. 2012, 370, 2418-2432. [CrossRef]

76. Boutry, C.M.; Chandrahalim, H.; Streit, P.; Schinhammer, M.; Hänzi, A.C.; Hierold, C. Characterization of miniaturized RLC resonators made of biodegradable materials for wireless implant applications. Sens. Actuators A Phys. 2013, 189, 344-355. [CrossRef]

77. Li, C.; Ahn, C.H.; Shutter, L.A.; Narayan, R.K. Toward real-time continuous brain glucose and oxygen monitoring with a smart catheter. Biosens. Bioelectron. 2009, 25, 173-178. [CrossRef]

78. Cordeiro, C.A.; Sias, A.; Koster, T.; Westerink, B.H.C.; Cremers, T.I.F.H. In vivo "real-time" monitoring of glucose in the brain with an amperometric enzyme-based biosensor based on gold coated tungsten (W-Au) microelectrodes. Sens. Actuators B Chem. 2018, 263, 605-613. [CrossRef]

79. Kojima, J.; Hosoya, S.; Suminaka, C.; Hori, N.; Sato, T. In integrated glucose sensor with an all-solid-state sodium ion-selective electrode for a minimally invasive glucose monitoring system. Micromachines 2015, 6, 831-841. [CrossRef]

80. Bollella, P.; Sharma, S.; Cass, A.E.G.; Antiochia, R. Microneedle-based biosensor for minimally-invasive lactate detection. Biosens. Bioelectron. 2019, 123, 152-159. [CrossRef]

81. Schumacher, S.; Stahl, J.; Bäumer, W.; Seitz, J.-M.; Bach, F.-W.; Petersen, L.J.; Kietzmann, M. Ex vivo examination of the biocompatibility of biodegradable magnesium via microdialysis in the isolated perfused bovine udder model. Int. J. Artif. Organs 2011, 34, 34-43. [CrossRef] [PubMed]

82. Ulrich, A.; Ott, N.; Tournier-Fillon, A.; Homazava, N.; Schmutz, P. Investigation of corrosion behavior of biodegradable magnesium alloys using an online-micro-flow capillary flow injection inductively coupled plasma mass spectrometry setup with electrochemical control. Spectrochim. Acta Part B Atomic Spectrosc. 2011, 66, 536-545. [CrossRef]

83. Su Natasha, M.; Malon, R.S.P.; Wicaksono, D.H.B.; Córcoles, E.P.; Hermawan, H. Monitoring magnesium degradation using microdialysis and fabric-based biosensors. Sci. China Mater. 2018, 61, 643-651. [CrossRef]

84. Frosch, K.-H.; Stürmer, K.M. Metallic biomaterials in skeletal repair. Eur. J. Trauma 2006, 32, $149-159$. [CrossRef]

85. Peichl, P.; Holzer, L.A.; Maier, R.; Holzer, G. Parathyroid hormone 1-84 accelerates fracture-healing in pubic bones of elderly osteoporotic women. JBJS 2011, 93, 1583-1587. [CrossRef] [PubMed] 
86. Jehle, P.M.; Schulten, K.; Schulz, W.; Jehle, D.R.; Stracke, S.; Manfras, B.; Boehm, B.O.; Baylink, D.J.; Mohan, S. Serum levels of insulin-like growth factor (IGF)-I and IGF binding protein (IGFBP)- 1 to- 6 and their relationship to bone metabolism in osteoporosis patients. Eur. J. Intern. Med. 2003, 14, 32-38. [CrossRef]

87. Good, D.M.; Thongboonkerd, V.; Novak, J.; Bascands, J.-L.; Schanstra, J.P.; Coon, J.J.; Dominiczak, A.; Mischak, H. Body fluid proteomics for biomarker discovery: Lessons from the past hold the key to success in the future. J. Proteome Res. 2007, 6, 4549-4555. [CrossRef] [PubMed]

(C) 2019 by the authors. Licensee MDPI, Basel, Switzerland. This article is an open access article distributed under the terms and conditions of the Creative Commons Attribution (CC BY) license (http://creativecommons.org/licenses/by/4.0/). 